\title{
Congenital Club Foot in Children Younger than 24 Months: Decancelous Cuboid Combined with Selective Soft Tissue Release
}

\author{
Nguyen Ngoc Hung \\ Vietnam National Hospital for Pediatrics, Hanoi, Vietnam. \\ Email: ngocyenhung@gmail.com \\ Received July $5^{\text {th }}, 2012$; revised August $15^{\text {th }}, 2012$; accepted August $26^{\text {th }}, 2012$
}

\begin{abstract}
Purpose: To evaluate 2 surgical prosedures in treatment of congenital clubfeet in children younger than 24 months. Materials and Methods: Data were analyzed on 319 patients (448 feet) from July 1990 to December 2005. Clinical and classification for all patients according to Diméglio. Operated patients were divided into two groups: group 1, selective soft tissue release; and group 2, selective soft tissue release combined with cuboid decancellation. Surgical results were classified according to McKay's system. Results: There were 103 females (32.3\%) and 216 males (67.7\%) in this study. There were 192 patients (268 feet) in group 1, 127 patients (180 feet) in group 2. Bilateral involvement was found in 129 patients $(40.4 \%)$, only the left foot affected in 65 patients $(20.4 \%)$, and only the right in 125 patients (39.2\%). According to the classification of Diméglio Grade II was seen in $32.4 \%$, Grade III in $53.1 \%$, and Grade IV in $14.5 \%$. Postoperatively, in group 1, we got excellent result in $29.1 \%$, good result in $49.2 \%$, fair result in $18.3 \%$, and poor result in $3.4 \%$. In group 2, we attained excellent result in $50.6 \%$, good result in $42.2 \%$, fair result in $6.1 \%$ and poor result in $1.1 \%$. The good to excellent result in group 2 was significantly higher in group 1 with $p=0.000042$. There was no failure in both groups. Residual adduction of forefoot in frontal plane was seen in $78.0 \%$ of group 1 , and $10.6 \%$ of group 2, which was also statistically significant with $\mathrm{p} \sim 0$. Conclusion: Generally speaking, the procedure of selective soft tissue releases combined with cuboid decancellation showed an outstanding result with good to excellent result of $92.8 \%$. Surgical procedure is simple, safe, and applicable for all patients with clubfeet's deformyties.
\end{abstract}

Keywords: Congenital Clubfoot; Forefoot Adduction; Position of Navicular; Posteromedial Release; Cuneiform Bones Osteotomy

\section{Introduction}

Idiopathic congenital talipes equinovarus (clubfoot) is a common complex deformity that occurs in approximately one or two per 1000 newborns [1]. The entire population of New Zealand is 4 million people. Of these, 750,000 people claimed Polynesian ethnic background in the 2001 census. With an estimated incidence of 6.8 clubfeet per 1000 in Polynesian populations [2], compared with one per 1000 in white European populations, pediatric orthopaedic surgeons in New Zealand treat a large number of clubfeet $[3,4]$.

Treatment of clubfoot has been controversial because initial correction of the deformity can be attained with both primarily nonsurgical and surgical methods [5]. The long-term goal of treatment is a functional, pain-free, plantigrade foot with good mobility, without calluses, and without the need for shoe-wear modification $[6,7]$.

Many investigators have reported short-term success, in terms of correction of clubfoot, with use of the Ponseti method of treatment with serial manipulations and casts $[8,9]$. In addition, good foot function was reported more than twenty-five years after the treatment of clubfeet by Ponseti $[6,7]$. As a result of these reports, the number of children undergoing extensive surgical soft-tissue releases has decreased. However, extensive soft-tissue releases are often performed when the results of the Ponseti method are inadequate, in children with resistant clubfoot, or because of recurrence secondary to poor compliance with bracing $[8,10]$.

Extensive soft-tissue releases frequently provide definitive correction [11], but they may have short-term complications and up to $47 \%$ of patients need additional surgery $[8,12,13]$. With few exceptions $[13,14]$ surgical techniques are recommended if correction of the foot using conservative methods within 3 to 6 months is not completely satisfactory. The range of early surgical methods is from posterior-only releases [15-17] to postero- 
medial [18] or posterolateral releases [19] and ultimately extended peritalar releases $[20,21]$

The purpose of this study was to determine the longterm results of two groups of patients in whom idiopathic clubfoot had been treated with a selective soft tissue release and a selective soft tissue release combined cuboid decancellation in children younger 24 months

\section{Material and Methods}

A retrospective study was undertaken on 356 patients (496 feet) with congenital club foot diagnosed from July 1990 to December 2005 by compatible symptoms and signs and confirmed by imaging studies.

We excluded patients who had any other anomaly, such as spina bifida, neurological disorders, arthrogryposis, idiopathic metatarsus adductus, congenital constriction bands or systemic disorders and had had no previous surgical treatment were excluded.

Thirty seven patients ( 48 feet) were excluded from the study due to lost follow-up or would or could not return for the final evaluation in this study. The remaining 319 patients (448 feet) formed the basis of this study.

The 319 patients ( 216 boys and 103 girls) with 448 feet had 190 unilateral (125 right and 65 left) and 129 bilateral cases.

In twenty six cases, incidence of clubfoot occurred in parents, siblings, or grandparents.

There were 67 feet ( 49 patients) operated before age 6 months, 100 feet (72 patients) operated between 6 months to 12 months, 187 feet (135 patients) operated between 12 months to 18 months, and 94 feet (63 patients) operated between 18 months to 24 months. The average age at time of surgery was 12.6 months.

The follow-up average, 15 years 7 months (range, 11 years 8 months to 20 years 3 months) in group 1; The followup average, 6 years 4 months (range, 5 years 6 months to 11 years 2 months) in group 2 .

Those patients were separated two groups: 1) Group 1 [from July 1990 to December 1999 in 192 patients (268 feet)] who were operated according to selective soft tissue release; 2) Group 2 [from January 2000 to December 2005 in 127 patients (180 feet)] who were operated according to selective soft tissue release and cuboid decancellation involved.

One surgeon (the author) performed all operations.

Those patient were indicated treatment when who underwent four to under 10 months of cast treatment with the French physiotherapy method and brace had failed to achieve a complete correction (48 feet of 34 patients in first 4 months of life, 67 feet of 47 patients in first 6 months of life, 109 feet of 79 patients in first 8 months of life, 170 feet of 117 patients in first 10 months of life) and 54 feet of 42 patients without treatment by manipu- lation and a cast and brace. In addition, each patient's gait was inspected, and the patients and the parents were questioned regarding the presence of pain, shoe wear problems, or other difficulties

\subsection{Clinical Examination}

Information gathered from the medical records included demographic data (including the sex of the patient), laterality of the clubfoot, age at initiation of treatment, duration of cast treatment before the surgery, age at the time of surgery, duration of cast treatment after the surgery, and details of surgical procedures.

The clinical examination included assessment of the patient's height and weight, limb lengths (measured from the anterior superior iliac spine to the medial malleolus), circumference of the calves (in centimeters), and length and width of the feet (in centimeters). The feet were inspected for evidence of calluses and were palpated for areas of tenderness.

An examination of the clubfoot should be performed initially and after each interval of treatment with manipulation and a cast. A reference point, usually the knee in $90^{\circ}$ of flexion, must be chosen for the examination of the foot. Torsional alignment, varus and valgus, and the overall size and shape of the leg, ankle, and foot should be assessed. Torsion is difficult to assess clinically in a patient with clubfoot because the medial malleolus is obscured by the navicular, atrophy of the calf is an expected component of clubfoot.

Equinus must be assessed with the knee both in extension and in flexion. The true contracture of the gastrocnemius-soleus muscle complex, which crosses the knee, is indicated by the equinus measured with the knee extended. The difference between the equinus measured with the knee flexed and that measured with it extended indicates the amount of stiffness in the ankle joint. The posterior aspect of the calcaneus must be palpated carefully when the equinus is measured because the bone may be pulled proximally away from the heel pad.

The varus or valgus position of the heel at rest and in the position of best correction should be measured. Flexibility of the subtalar joint is difficult to measure but may give an indication about stiffness.

The talar head should be palpated dorsolaterally at the midfoot. The talar head usually is lined up with the patella, although in plantar flexion. Manipulation to reduce the forefoot onto the talar head indicates the amount of midfoot stiffness.

Forefoot supination should be noted. All deformities should be assessed in relation to the next most proximal segment-i.e., the forefoot on the midfoot, the midfoot on the hindfoot, and the hindfoot on the ankle. If the hindfoot is in $30^{\circ}$ of varus and the forefoot (the line of 
the toes) is angulated $30^{\circ}$ in relation to the tibia, then the deformity is hindfoot varus and there is no forefoot supination. Errors in this assessment may lead the surgeon to overcorrect the forefoot in a cast or to surgically create a pronation deformity [22].

Palpation of the lateral column with the foot in dorsiflexion can demonstrate overcorrection of the midfoot (iatrogenic rocker-bottom foot).

Gait was observed for limping. A handheld goniometer was used to measure passive dorsiflexion and plantar flexion of the ankle with the knee straight as well as supination and pronation of the forefoot and varus-valgus movement of the heel.
Clinical evaluation and classification for all patient according to Diméglio et al. [23]. The system of Diméglio et al. is derived from a detailed scoring system based on the measurement of four parameters: 1) equinus in the sagittal plane; 2) varus deviation in the frontal plane; 3) "derotation" around the talus of the calcaneoforefoot block; and 4) adduction of the forefoot on the hindfoot in the horizontal plane. The scale includes four additional points for the presence of medial creases, a posterior crease, cavus and poor calf musculature. From the score, which has a maximum of 20 points, the deformity can be graded as benign, moderate, severe or very severe (Table 1).

Table 1. The system of Diméglio et al. [23] for the classification of congenital talipes equinovarus.

\begin{tabular}{cccc}
\hline Classification Grade & Type & Score & Reducibility \\
\hline$\underline{\text { I }}$ & Benigin & $<5$ & $<90 \%$, soft-soft, resolving \\
II & Moderate & 5 to $<10$ & $>50 \%$, reducible, partly resistant \\
$\underline{\text { III }}$ & Severe & 10 to $<15$ & $<50 \%$, resistant, partly reducible \\
$\underline{\text { IV }}$ & Very severe & 15 to $<20$ & $<10 \%$, resistant \\
\hline
\end{tabular}

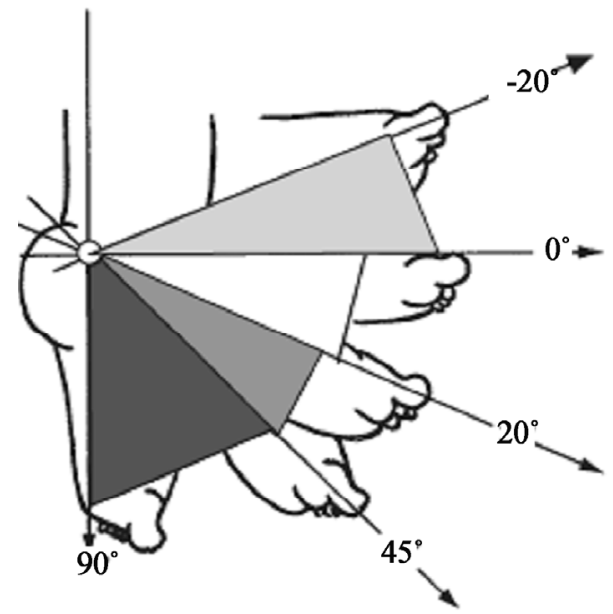

a. Sagittal plane: evaluation of equinus

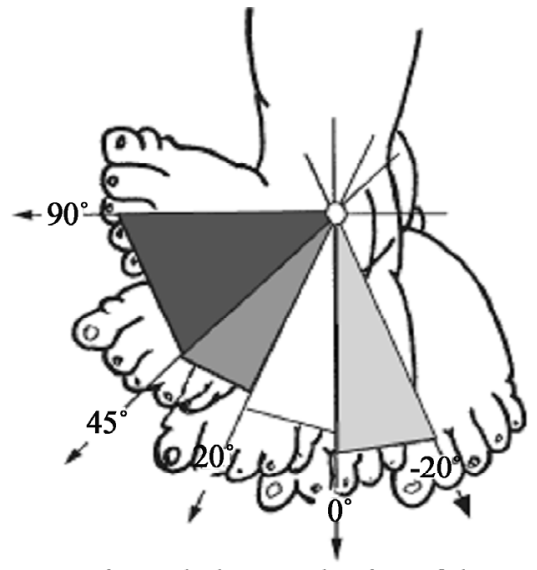

c. Horizontal plane evaluation of derotation d. Horizontal plane:

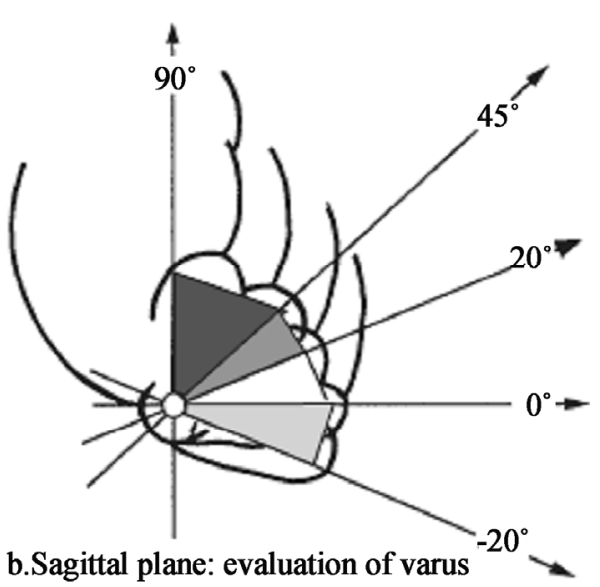

$\square \quad 1$ point
$\square \quad 2$ points
$\square \quad 3$ points
$\square \quad 4$ points

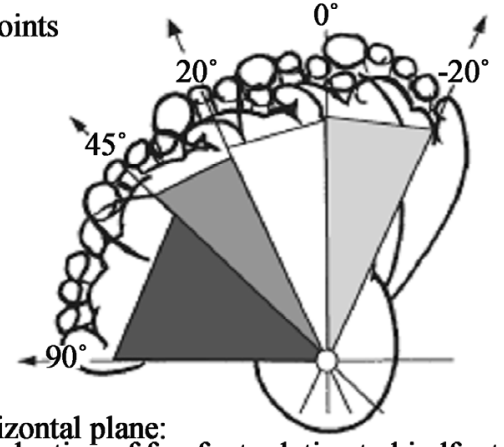

evaluation of forefoot relative to hindfoot 


\subsection{Radiographic Examination}

Radiographs made preoperation, Postoperative 3 months, Posoperative 6 months, Posoperative 12 months and last follow up. Radiographic examination with anteroposterior and lateral radiographs of the affected foot, as well as the contralateral, normal foot when applicable, were made with the patient standing. The anteroposterior talocalcaneal angle, the angle between the calcaneus and the fifth metatarsal, and the angle between the long axis of the talus and the first metatarsal were measured on the anteroposterior radiographs [24]. The lateral talocalcaneal angle were measured on the lateral radiographs [24,25].

\subsection{Surgical Procedure}

The patient is initially positioned in the supine position on the surgical table. The affected limb is prepared and draped free in a sterile fashion. The limb is exsanguinated by elevation and the tourniquet is elevated.

\subsection{Selective Soft Tissue Release}

The first incision, percutaneous achilles tenotomy with the assistant holding the foot in maximum dorsiflexion, select a site about $1.5 \mathrm{~cm}$ above the calcaneus for the tenotomy with incision $0.5-1.0 \mathrm{~cm}$ posterior and superior heel $1 \mathrm{~cm}$. Keep in mind the anatomy. The neurovascular bundle is anteromedial to the heel cord. The heel-cord tendon (light blue) lies within the tendon sheath (grey). The initial entry causes a small longitudinal incision. Care must be taken to be gentle so as not to accidentally make a large skin incision. The tendon sheath (grey) is not divided and left intact. An additional 15 to 20 degrees of dorsiflexion is typically gained after the tenotomy. If the feet having $<5^{\circ}$ of ankle dorsiflexion with knee straight, performing the posterior tibiotalar capsulotomy.

In a severe clubfoot, the posterior edge of the calcaneus may be in direct contact with the posterior border of the tibia, obscuring the talus. Addtional insion posterior and superior heel $2 \mathrm{~cm}$. To facilitate this exposure, the fibrofatty tissue and capsule over the posterior aspect of the joint are sharply excised with a knife. The tibiotalar joint can be identified by palpation and inspection while the foot is flexed and extended.

The second incision, the skin incision was made on the medial aspect of the foot $5 \mathrm{~cm}$ in accordance with the shape of its longitudinal and starts just in front of the medial cuneiform bone and runs backwards along the line of the tendon of tibialis posterior, beneath the medial malleolus. 1) The tendon of tibialis posterior is exposed throughout its length from medial malleolus to its insertion into the navicular bone. The tendon must be dissected free of this slab of tissue and the tissue mass ex- cised to expose the talo-navicular joint. The tendon is then lengthened by Z-plasty, taking care to allow for a substantial increase in length; 2) The capsule of the talonavicular joint is divided on its superior, medial and inferior surfaces to allow free lateral movement of the navicular on the talus; 3) Naviculo-medial cuneiform capsulotomy; and 4) Define tibiocancaneal ligament, part of Deltoid ligament and it was transected (Superior deltoid ligament) when varus position of heel more than $20^{\circ}$.

\subsection{Decancelous Cuboid}

The cuboid is exposed through a separate longitudinal lateral foot incision $4 \mathrm{~cm}$, starts just in front of the middle distal five and four metatarsus to beneath the lateral malleolus (see Figure 1(a)). Sharp dissection is then performed down to the level of the cuboid. The inferior edge of the extensor brevis communis muscle is sharply defined. The cuboid is exposed extraperiosteally to its dorsal surfaces. Exposure is completed by carefully identifying the calcaneocuboid and cubio-fifth metatarsal joints by dorsiflexion and plantarflexion (without opening those joints capsule). To create a small lid of lozenge on dorsal surface of cuboid with two diameter 5 and 8 mm (see Figures 1(b) and 2). Performing decancelous cuboid gently by small curette (see Figures 1(c) and 3). Then, rotational pronation and abductional foot $20^{\circ}$ and, rotational pronation of the forefoot at this midfoot allows correction of the supination; closure of the lozenge was achieved and held with Kirschner wire $1.5 \mathrm{~mm}$ passing through the fifth metatarsal, cuboid, and calcaneum (see Figures 1(d) and 4-6).

Checking talonavicular Joint, thus skin incision was made on the medial aspect of the foot, exposing more of the medial surface of the head of talus and navicula could be seen the navicula have moved laterally on the head of the talus. The wounds are closed.

\subsection{Aftercare}

The foot was immobilized in an above-the-knee plaster cast maintaining the knee in $60^{\circ}$ flexion, abductional foot $20^{\circ}$. The first cast change was after 1 week. The second cast change was after 3 week after surgery, the feet were held in a padded. The third cast change was after 6 week after surgery. During this change, a below-knee plaster cast was applied and retained for 6 weeks. The total cast time was 12 weeks. Then, the Kirschner wire was removed and a below-knee plaster cast was applied for the next 8 weeks. An ankle-foot orthosis with ankle hinge with limited plantar flexion and lateral strap was applied full time for 6 months. After ankle-foot orthosis was removed, a splint was worn permanently for 2 to 3 years overnight. Intensive physiotherapy was done to improve 


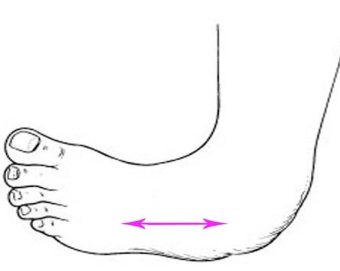

(a)

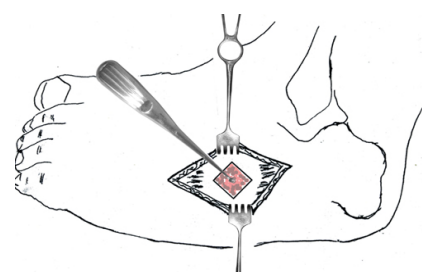

(c)

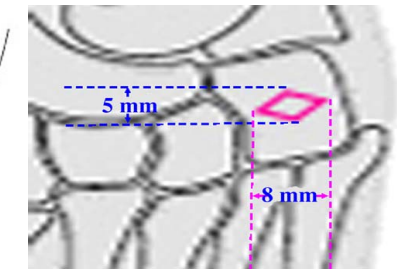

(b)

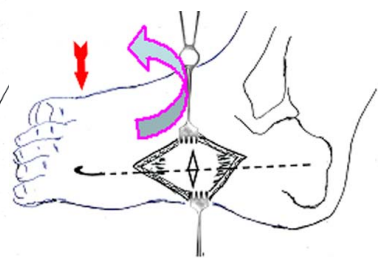

(d)
Figure 1. (a) Incision $4 \mathrm{~cm}$, starts just in front of the middle distal five and four metatarsus to beneath the lateral malleolus; (b) To create a small lid of lozenge on dorsal surface of cuboid with two diameter 5 and $8 \mathrm{~mm}$; (c) Performing decancelous cuboid gently by small curette; (d) Pronator rotation of the forefoot at this midfoot allows correction of the supination and abduction $20^{\circ}$; closure of the lozenge was achieved and held with Kirschner wire $1.5 \mathrm{~mm}$ passing through the five metatarsal, cubiod, and calcaneum.

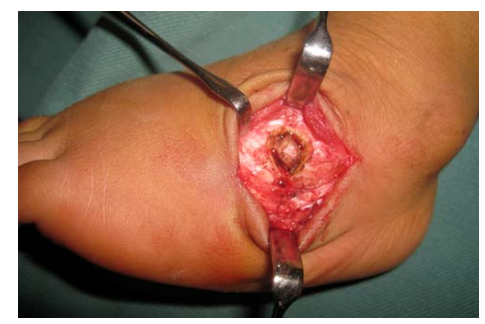

Figure 2. To create a small lid of lozenge on dorsal surface of cuboid.

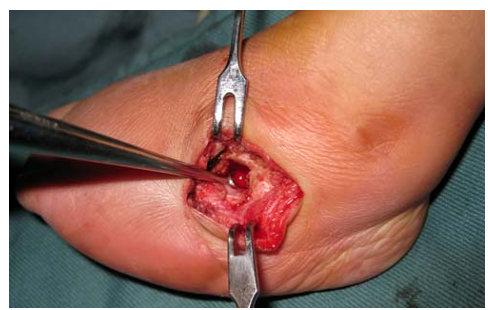

Figure 3. Remove decancelous cuboid by small curette.

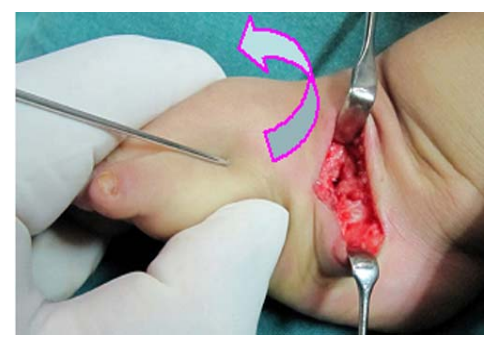

Figure 4. Derotational pronation and abductional foot 20.

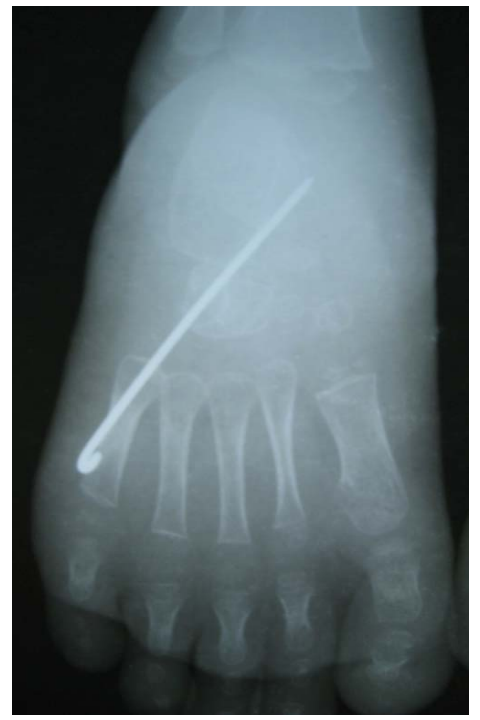

Figure 5. Kirschner wire passing through the five metatarsal, cubiod, and calcaneum on AP radiograph.

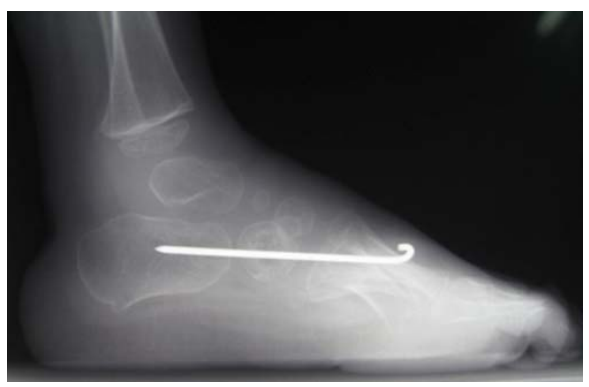

Figure 6. Kirschner wire passing through the five metatarsal, cubiod, and calcaneum on lateral radiograph.

range of motion (ROM) and to strengthen the pronator muscles.

\subsection{Methods of Followup}

We graded the clinical result about clinical evaluation was based on the judgment of foot shape and the ROM in the upper and lower ankle. In unilateral clubfeet, the differences in calf circumference and foot length also were measured.

For assessment of treatment results, the score of McKay [20] was used. This score represents well-balanced aspects of pain, shape, and function of the foot (Table 2). The results, subtracted from 180 points, were classified according to McKay [20] as follows: 175 - 180 points, excellent; 160 - 174 points, good; 125 - 159 points, fair; 90 124 points, poor; and less than 90 points, failure.

\section{Result}

There were 2 groups, from January 1991 to December 1999 with 192 patients (bilateral in 76 patients), 268 feet 
Table 2. Overall rating system for judging corrected clubfoot according to McKay [20].

\begin{tabular}{|c|c|c|c|}
\hline \multicolumn{2}{|c|}{ Category } & \multicolumn{2}{|c|}{ Subtract from 180 points } \\
\hline \multicolumn{4}{|l|}{ 1. Ankle motion } \\
\hline Greater than $90^{\circ}$ & Less than $90^{\circ}$ & Total & \\
\hline 10 & 40 & 50 & 0 \\
\hline 10 & 30 & 40 & -10 \\
\hline 10 & 25 & 25 & -20 \\
\hline Less than 10 & Less than 25 & Less than 35 & -30 \\
\hline \multicolumn{4}{|c|}{ 2. Angle of bimalleolar plane to longitudinal plane of foot } \\
\hline $83^{\circ}$ to $90^{\circ}$ & & & 0 \\
\hline $76^{\circ}$ to $82^{\circ}$ & & & -10 \\
\hline $50^{\circ}$ to 75 & & & -20 \\
\hline \multicolumn{4}{|c|}{ 3. Strength of triceps surae } \\
\hline Weight supported on $t$ & foot only & & 0 \\
\hline Weight supported on & h feet & & -10 \\
\hline Weight not supported & & & -20 \\
\hline \multicolumn{4}{|l|}{ 4. Heel } \\
\hline $0^{\circ}$ to $5^{\circ}$ valgus & & & 0 \\
\hline $5^{\circ}$ to $10^{\circ}$ valgus & & & -5 \\
\hline Greater than $10^{\circ}$ valgu & & & -10 \\
\hline Varus & & & -10 \\
\hline \multicolumn{4}{|l|}{ 5. Forefoot } \\
\hline Neutral & & & 0 \\
\hline To $5^{\circ}$ adduction or $a b$ & & & -5 \\
\hline Greater than $5^{\circ}$ & & & -10 \\
\hline \multicolumn{4}{|c|}{ 6. Flexor hallucis longus } \\
\hline Functional & & & 0 \\
\hline Nonfunctional & & & -10 \\
\hline \multicolumn{4}{|l|}{ 7. Ankle pain } \\
\hline Constantly disabling & & & -30 \\
\hline Tolerable during daily & & & -20 \\
\hline Limping at end of day & & & -10 \\
\hline Interferes only with ru & & & -5 \\
\hline \multicolumn{4}{|l|}{ 8. Subtalar pain } \\
\hline Constantly disabling & & & -20 \\
\hline Tolerable during daily & & & -20 \\
\hline Limping at end of day & & & -10 \\
\hline Interferes only with ru & & & -5 \\
\hline \multicolumn{4}{|l|}{ 9. Shoe wear } \\
\hline Stylish shoes foregone & & & -5 \\
\hline Foot deforms shoes & & & -10 \\
\hline Shoes do not fit & & & -15 \\
\hline \multicolumn{4}{|l|}{ 10. Sports } \\
\hline Competitive & & & 0 \\
\hline Noncompetitive becau & & & -15 \\
\hline
\end{tabular}


in group 1. From January 2000 to December 2005 with 127 patients (bilateral in 53 patients), 180 feet in group 2.

\section{Classification}

Age at operative time: Overall, $50(15.7 \%)$ patients in 4-6 montths, $71(22.3 \%)$ patients in $6-12$ months, 135 (42.3\%) patients in 12 - 18 months, and $63(19.7 \%)$ patients in $18-24$ months.

There were $30(15.6 \%)$ patients with bilateral $10 \mathrm{pa}-$ tients in 4 - 6 months; 46 (24.0\%) patients with bilateral 17 patients in $6-12$ months; $78(40.6 \%)$ patients with bilateral 29 patients in 12 - 18 months; $38(19.8 \%)$ patients with bilateral 20 patients in $18-24$ months in group 1.

There were $19(15.0 \%)$ patients with bilateral 8 patients in 4 - 6 months; 26 (20.5\%) patients with bilateral 11 patients in $6-12$ months; 57 (44.9\%) patients with bilateral 23 patients in 12 - 18 months; $25(19.7 \%)$ patients with bilateral 11 patients in $18-24$ months in group 2.

All patients (448 feet of 319 patients) were performed surgical technique with Lengthening posterior Tibial tendon, Percutaneous Achilles tenotomy, TaloNavicular capsulotomy, and naviculo-medial cuneiform capsulotomy. The Posterior TibioTalar Capsulotomy 28 feet (10.4\%) in group 1, and 16 feet $(8.9 \%)$ in group 2 . The Deltoid ligamentomy 179 feet $(66.8 \%)$ in the group 1, and 124 feet $(68.9 \%)$ in the group 2

\section{Clinical Results}

Postoperatively, all patient improvement with clubfeet's deformities. Eight patients in group 1 and three patients in group 2 reported pain during daily or strenuous activity. All but 19 feet in 12 patients in group 1 and 7 feet in 5 patients in group 2 (or their parents) were not satisfied with the treatment results. All other patients, except for 8 patients in group 1 and 2 patients in group 2, they had nearly normal walking ability and wore normal shoes.

- Rotation of entire foot in horizontal plane improvement to normal foot in $240(89.6 \%)$ feet of 171 patients, remaining 28 feet of 21 patients with $>5^{\circ}-\leq 10^{\circ}$ in 19 feet and $>10^{\circ}-\leq 20^{\circ}$ in 9 feet in the group 1. Rotation of entire foot in horizontal plane improvement to normal foot in $170(94.4 \%)$ feet of 119 patients, remaining 10 feet of 8 patiens with $>5^{\circ}-\leq 10^{\circ}$ in 8 feet of 6 patients and $>10^{\circ}-\leq 20^{\circ}$ in 2 feet of 2 patient in group 2 .

- Varus in frontal plane improvement to normal foot in 213 (79.5\%) feet of 152 patients, remaining 55 feet of 40 patients with $>5^{\circ}-\leq 10^{\circ}$ in 38 feet of 29 patients and $>10^{\circ}$ $\leq 20^{\circ}$ in 17 feet of 11 patients in group 1. Varus in frontal plane improvement to normal foot in $153(85.0 \%)$ feet of 107 patients, remaining 27 feet of 20 patients with $>5^{\circ}$ - $\leq 10^{\circ}$ in 21 feet of 16 patients and $>10^{\circ}-\leq 20^{\circ}$ in 6 feet of 4 patients in group 2 .

- In the group 1, two hundred and one feet (75.0\%) of 144 patients had residual forefoot adduction of $10^{\circ}$ to $20^{\circ}$ treated by overnight splints and insoles; and 8 feet $(3.0 \%)$ of 5 patients also had residual forefoot adduction of $20^{\circ}$ to $25^{\circ}$ treated by additional surgery. In the group 2,19 feet $(10.6 \%)$ of 14 patients also had residual forefoot adduction of $10^{\circ}$ to $20^{\circ}$ treated by overnight splints and insoles.

- Equinus in sagittal plane improvement to normal foot in $258(96.3 \%)$ feet of 184 patients, remaining 10 feet of 8 patients with $>5^{\circ}-\leq 10^{\circ}$ in 6 feet of 5 patients, $>10^{\circ}$ $\leq 20^{\circ}$ in 4 feet of 3 patients in group 1. Equinus in sagittal plane improvement to normal foot in $176(97.8 \%)$ feet of 124 patients, remaining 4 feet of 3 patients with $>5^{\circ}$ $\leq 10^{\circ}$ in 1 feet of 1 patient, $>10^{\circ}-\leq 20^{\circ}$ in 3 feet of 2 patients in group 2.

In the lower ankle, there were 171 feet of 123 patients could be pronated at least to the zero position, and 97 feet of 69 patients beyond the zero position in group1; there were 109 feet of 73 patients could be pronated at least to the zero position, and 71 feet of 54 patients beyond the zero position in group 2. In the upper ankle, there were 223 feet of 159 patients had active dorsiflexion beyond the zero position, and 45 feet of 33 patients reached only the zero position in group 1 ; there were 168 feet of 119 patients had active dorsiflexion beyond the zero position, and 12 feet of 8 patients reached only the zero position in group 2. Comparing the 190 unilateral treatments with the contralateral side, the mean difference in calf circumference was $2.2 \mathrm{~cm}$ (range, 1.0 - 3.4 $\mathrm{cm}$ ) and in foot length was $0.9 \mathrm{~cm}$ (range, $0-1.4 \mathrm{~cm}$ ).

There were 61 feet of 44 patients were followed up to skeletal maturity: Excellent result in 12 feet (19.7\%) of 8 patients, good result in 21 feet $(34.4 \%)$ of 14 patients, fair result in $22(36.1 \%)$ feet of 18 patients, and 6 feet $(9.8 \%)$ of 4 patients.

\subsection{Radiographic Results}

- The mean talocalcaneal angle index improved from $26.8^{\circ}$ pre-operatively to $70.6^{\circ}$ at the last followup in goup 1 ; from $26.5^{\circ}$ pre-operatively to $73.8^{\circ}$ at the last followup in group 2.

- Compared with the normal feet, the clubfeet had decreased anteroposterior and lateral talocalcaneal angles, indicating residual heel varus. On lateral projection, Talocalcaneal angle improved from $8.9^{\circ}\left(6.5^{\circ}-15.1^{\circ}\right)$ preoperatively to $38.4^{\circ}\left(33.7^{\circ}-44.9^{\circ}\right)$ at the last followup in goup 1; from $7.8^{\circ}\left(6.6^{\circ}-14.3^{\circ}\right)$ pre-operatively to $40.7^{\circ}$ $\left(34.1^{\circ}-43.5^{\circ}\right)$ at the last followup in group 2. On AP projection, Talocalcaneal angle improved from $13.9^{\circ}$ 
$\left(12.8^{\circ}-25.2^{\circ}\right)$ pre-operatively to $32.2^{\circ}\left(27.3^{\circ}-39.6^{\circ}\right)$ at the last followup in goup 1 ; from $14.1^{\circ}\left(13.1^{\circ}-25.6^{\circ}\right)$ pre-operatively to $33.1^{\circ}\left(31.7^{\circ}-40.5^{\circ}\right)$ at the last followup in group 2.

- The anteroposterior talus-first metatarsal angle and the calcaneus-fifth metatarsal angle in the clubfeet reflected residual forefoot adduction. The mean talo-first metatarsal angle improved from $24.5^{\circ}\left(22.1^{\circ}-42.7^{\circ}\right)$ to $21.5^{\circ}\left(19.6^{\circ}-28.7^{\circ}\right)$ at the last followup in group 1 ; from $25.1^{\circ}\left(20.9^{\circ}-39.5^{\circ}\right)$ to $14.5^{\circ}\left(11.2^{\circ}-20.4^{\circ}\right)$ at the last followup in group 2 with decancelous cuboid.

- The meam calcaneus-fifth metatarsal angle improved from $23.7^{\circ}\left(18.4^{\circ}-39.6^{\circ}\right)$ to $9.5^{\circ}\left(7.5^{\circ}-14.4^{\circ}\right)$ at the last followup in group 1 ; from $24.9^{\circ}\left(19.3^{\circ}-42.3^{\circ}\right)$ to $4.2^{\circ}$ $\left(3.1^{\circ}-5.2^{\circ}\right)$ at the last followup in group 2 .

- Talonavicular subluxation was present in each case in which the talo-first metatarsal angle on the AP view was greater than $15^{\circ}$ and combined with a talocalcaneal angle of less than $15^{\circ}$ are helpful [51]. Preoperatively, 92 of 268 feet $(34.3 \%)$ in the group 1, and 69 of 180 feet $(38.3 \%)$ in the group 2 were presented Talonavicular subluxation. Last follow up, this deformities remaining 52 of 268 feet (19.4\%) in the group 1, and 7 of 180 feet $(3.9 \%)$ in the group 2 were presented Talonavicular subluxation.

- The mean length of the medial column increased from $3.1 \mathrm{~cm}$ preoperatively to $4.2 \mathrm{~cm}$ at final follow-up. The mean cuboid or lateral column length was $2.6 \mathrm{~cm}$ preoperatively and at final follow-up. These length changes led to an increase in the ratio of medial-to-lateral column length from a mean value of 1.2 preoperatively to a mean value of 1.6 at final follow-up, an increase of $33 \%$.

- Radiographic evidence revealed a rare incidence of bone and joint deformities at followup. Distinct osteoporosis of the foot or degenerative changes of the tarsal and midtarsal joints were not evident. The degenerative changes of talonavicular, naviculo-medial cuneiform, calcaneocuboid, and cubo-fifth metatarsal joints were not evident.

Excellent and good with club feet in patient younger 12 months were $69(67 \%)$ feet in the group 1. Excellent and good with club feet in patient younger 12 months were $57(89.1 \%)$ feet in the group 2. Excellent and good with club feet in patient older 12 months were 141 (85.5\%) feet in the group 1. Excellent and good with club feet in patient older 12 months were $110(94.8 \%)$ feet in the group 2.

Overall, Age at time operation both two groups, Excellent or Good results, results in group 2 better than group 1.

Overall late result, Excellent in 169 (37.7\%), Good in 208 (46.4\%), Fair 60 (13.4\%), and Poor in 11 (2.5\%)
(Table 3).

We see surgical error: Injury of cuboid cartilagenious capsule in 1 foot, patient without free pain foot, final follow up is fair. Slide down of Kirchner wire in 1 foot postoperative 8 weeks, Kirschner wire was removed and place new plaster cast with abductor position $20^{\circ}$, final follow up is fair.

\subsection{Other Complication}

Flat foot in 6 feet $(1.3 \%)$ of 4 patients; intoeing gait of 5 feet $(1,1 \%)$ of 5 patients; Pseudoaneurysm of 2 feet $(0.5 \%)$ of 2 patients; Dorsal subluxation of the navicular 3 feet $(0.7 \%)$ of 3 patients; Avascular necrosis of talus 3 feet $(0.7 \%)$ of 2 patients; Dorsal bunion in 2 feet $(0.5 \%)$ of 2 patients.

\section{Discussion}

\subsection{Classification}

The treatment should be determined by the classification with reference to the different elements of the deformity, and it should predict the prognosis of the deformity at any stage and be used to compare the results of treatment. There were four classifications shows that each has specific problems: 1) The system of Ponseti and Smoley [26]; 2) Harrold and Walker's system [27]; 3) Catterall's system [28]; and 4) Diméglio et al. [23]. The system of Diméglio et al. [23] appears to be most reliable for consultants, so our patients have been classificated according to Diméglio (see Table 4).

\subsection{Clinic and X-Ray}

Because conventional radiography cannot give any reliable information at this young age, one has to be content with the clinical examination in the decision regarding the type of surgery.

Today, Tuncay et al. [29] do not consider the clinical examination as the main criterion in the decision as to which type of surgery and the clinical examination alone is not sufficient to determine the type of the surgical intervention needed in idiopathic clubfoot, the decision must be supported by the radiologic parameters.

We prefer to consider the clinical examination and document of radiographicss invonlved for type of the surgical intervention needed in idiopathic clubfoot, prognosis, and follow up (see Tables 5-7).

\subsection{Surgical Procedure}

Yamamoto et al. [30] showed an effectiveness of nonsurgical treatment only in mild and moderate deformities. In severe deformities, the treatment only sometimes was effective. 
Soft Tissue Release

Table 3. Latest results.

\begin{tabular}{cccccc}
\hline & Excellent & Good & Fair & Poor & Failure \\
\hline Group 1 & 78 & 132 & 49 & 9 & 0 \\
$\mathrm{~N}=268$ feet & $(29.1 \%)$ & $(49.2 \%)$ & $(18.3 \%)$ & $(3.4 \%)$ & 2 \\
Group 2 & 91 & 76 & 11 & $(1.1 \%)$ & 0 \\
$\mathrm{~N}=180$ feet & $(50.6 \%)$ & $(42.2 \%)$ & $60(13.4 \%)$ & $11(2.5 \%)$ & \\
\hline
\end{tabular}

Table 4. Classification.

\begin{tabular}{|c|c|c|c|c|c|}
\hline & Excellent & Good & Fair & Poor & Failure \\
\hline Group $1 \mathrm{~N}=268$ feet & $78(29.1 \%)$ & $132(49.2 \%)$ & $49(18.3 \%)$ & $9(3.4 \%)$ & 0 \\
\hline \multirow[t]{2}{*}{ Group $2 \mathrm{~N}=180$ feet } & $91(50.6 \%)$ & $76(42.2 \%)$ & $11(6.1 \%)$ & $2(1.1 \%)$ & 0 \\
\hline & $169(37.7 \%)$ & $208(46.4 \%)$ & $60(13.4 \%)$ & $11(2.5 \%)$ & \\
\hline
\end{tabular}

Table 5. Clinical results.

\begin{tabular}{|c|c|c|c|c|c|c|}
\hline \multirow{3}{*}{ Deformyties } & \multirow{2}{*}{\multicolumn{2}{|c|}{ Normal }} & \multicolumn{4}{|c|}{ Degree of deformyties } \\
\hline & & & \multicolumn{2}{|c|}{$>5^{\circ}-\leq 20^{\circ}$} & \multicolumn{2}{|c|}{$>20^{\circ}-\leq 25^{\circ}$} \\
\hline & Group 1 & Group 2 & Group 1 & Group 2 & Group 1 & Group 2 \\
\hline Rotation of entire foot in horizontal plane & $240(89.6 \%)$ & $170(94.5 \%)$ & $28(10.4 \%)$ & $10(5.5 \%)$ & & \\
\hline Varus in frontal plane & $213(79.5 \%)$ & $153(85.0 \%)$ & $55(20.5 \%)$ & $27(15.0 \%)$ & & \\
\hline Adduction of forefoot in frontal plane & $59(22.0 \%)$ & $161(89.4 \%)$ & $201(75.0 \%)$ & $19(10.6 \%)$ & $8(3.0 \%)$ & 0 \\
\hline Equinus in sagittal plane & 258 (96.3\%) & $176(97.8)$ & $10(3.7 \%)$ & $4(2.2 \%)$ & & \\
\hline
\end{tabular}

Table 6. Radiographical result in the group 1.

\begin{tabular}{|c|c|c|c|c|c|}
\hline Angular measurement & Preoperative & $\begin{array}{l}\text { Postoperative } \\
3 \text { months }\end{array}$ & $\begin{array}{l}\text { Postoperative } \\
6 \text { months }\end{array}$ & $\begin{array}{l}\text { Postoperative } \\
12 \text { months }\end{array}$ & Final followup \\
\hline On lateral projection & $8.9^{\circ}$ & $30.3^{\circ}$ & $34.9^{\circ}$ & $35.2^{\circ}$ & $38.4^{\circ}$ \\
\hline Talocalcaneal angle & $\left(6.5^{\circ}-20.6^{\circ}\right)$ & $\left(17^{\circ}-54^{\circ}\right)$ & $\left(32.5^{\circ}-42.4^{\circ}\right)$ & $\left(32.8^{\circ}-43.7^{\circ}\right)$ & $\left(33.7^{\circ}-44.9^{\circ}\right)$ \\
\hline On AP projection & $13.9^{\circ}$ & $23.7^{\circ}$ & $31.9^{\circ}$ & $33.6^{\circ}$ & $32.2^{\circ}$ \\
\hline Talocalcaneal angle & $\left(12.8^{\circ}-25.2^{\circ}\right)$ & $\left(21.7^{\circ}-41.8^{\circ}\right)$ & $\left(24.2^{\circ}-40.4^{\circ}\right)$ & $\left(26.4^{\circ}-39.2^{\circ}\right)$ & $\left(27.3^{\circ}-39.6^{\circ}\right)$ \\
\hline On AP projection & $24.5^{\circ}$ & $23.7^{\circ}$ & $22.2^{\circ}$ & $21.7^{\circ}$ & $21.5^{\circ}$ \\
\hline Talo-first metatarsal angle & $\left(22.1^{\circ}-42.7^{\circ}\right)$ & $\left(19.3^{\circ}-31.4^{\circ}\right)$ & $\left(19.1^{\circ}-30.8^{\circ}\right)$ & $\left(18.8^{\circ}-29.6^{\circ}\right)$ & $\left(19.6^{\circ}-28.7^{\circ}\right)$ \\
\hline On AP projection & $23.7^{\circ}$ & $15.6^{\circ}$ & $14.4^{\circ}$ & $12.8^{\circ}$ & $9.5^{\circ}$ \\
\hline Calcaneus-fifth metatarsal & $\left(18.4^{\circ}-39.6^{\circ}\right)$ & $\left(14.2^{\circ}-19.5^{\circ}\right)$ & $\left(13.8^{\circ}-18.7^{\circ}\right)$ & $\left(9.1^{\circ}-15.2^{\circ}\right)$ & $\left(7.5^{\circ}-14.4^{\circ}\right)$ \\
\hline Talocalcaneal index & $26.8^{\circ}$ & $54.0^{\circ}$ & $66.8^{\circ}$ & $68.8^{\circ}$ & $70.6^{\circ}$ \\
\hline
\end{tabular}

\footnotetext{
"Measurements on Radiographs of the Foot in Normal Infants and Children according to Vanderwilde et al. [25]: On lateral projection, 15 ${ }^{\circ}$ - 60 in Talocalcaneal angle; On AP projection, $10^{\circ}-56^{\circ}$ in Talocalcaneal angle, $5^{\circ}-15^{\circ}$ in Talo-first metatarsal angle, $-18^{\circ}-5^{\circ}$ in Calcaneus-fifth metatarsal angle, and $45^{\circ}-$ $103^{\circ}$ in Talocalcaneal index.
} 
Table 7. Radiographical result in the group 2.

\begin{tabular}{|c|c|c|c|c|c|}
\hline Angular measurement & Preoperative & $\begin{array}{c}\text { Postoperative } \\
3 \text { months }\end{array}$ & $\begin{array}{c}\text { Postoperative } \\
6 \text { months }\end{array}$ & $\begin{array}{l}\text { Postoperative } \\
12 \text { months }\end{array}$ & Final followup \\
\hline On lateral projection & $7.8^{\circ}$ & $33.6^{\circ}$ & 35.1 & 39.5 & $40.7^{\circ}$ \\
\hline Talocalcaneal angle & $\left(6.6^{\circ}-14.3^{\circ}\right)$ & $\left(16^{\circ}-45^{\circ}\right)$ & $\left(32.9^{\circ}-38.4^{\circ}\right)$ & $\left(33.6^{\circ}-40.4^{\circ}\right)$ & $\left(34.1^{\circ}-43.5^{\circ}\right)$ \\
\hline Talocalcaneal angle & $\left(13.1^{\circ}-25.6^{\circ}\right)$ & $\left(23.6^{\circ}-42.6^{\circ}\right)$ & $\left(26.3^{\circ}-40.2^{\circ}\right)$ & $\left(30.4^{\circ}-40.7^{\circ}\right)$ & $\left(31.7^{\circ}-40.5^{\circ}\right)$ \\
\hline On AP projection & $25.1^{\circ}$ & $15.3^{\circ}$ & $14.1^{\circ}$ & $13.7^{\circ}$ & $14.5^{\circ}$ \\
\hline Talo-first metatarsal angle & $\left(20.9^{\circ}-39.5^{\circ}\right)$ & $\left(11.7^{\circ}-18.2^{\circ}\right)$ & $\left(12.8^{\circ}-18.6^{\circ}\right)$ & $\left(12.2^{\circ}-18.1^{\circ}\right)$ & $\left(11.2^{\circ}-20.4^{\circ}\right)$ \\
\hline On AP projection & $24.9^{\circ}$ & $11.2^{\circ}$ & $5.4^{\circ}$ & $4.5^{\circ}$ & $4.2^{\circ}$ \\
\hline Calcaneus-fifth metatarsal & $\left(19.3^{\circ}-42.3^{\circ}\right)$ & $\left(8.6^{\circ}-12.5^{\circ}\right)$ & $\left(3.9^{\circ}-6.4^{\circ}\right)$ & $\left(3.5^{\circ}-5.8^{\circ}\right)$ & $\left(3.1^{\circ}-5.2^{\circ}\right)$ \\
\hline Talocalcaneal index & $26.5^{\circ}$ & $60.1^{\circ}$ & $64.3^{\circ}$ & $71.7^{\circ}$ & $73.8^{\circ}$ \\
\hline
\end{tabular}

\subsection{Age at Operation}

Many orthopaedic surgeons agree that a severe clubfoot requires surgery and prefer early operative treatment when the patient is between 3 and 6 months of age. Neonatal clubfoot surgery and surgery in the first 3 months of life [31] has yielded disappointing results because of excessive scar tissue formation. We did not perform to operation for patient with classification Grade I of Diméglio and age at time operation $4-6$ months in 50 patients $(15,7 \%), 6-12$ months in 71 patients $(22.3 \%)$, 12 - 18 months in 135 patients (42.3\%), and $18-24$ months in 63 patients $(19.7 \%)$. It is noteworthy that six of the ten failures occurred in children who were operated on when they were less than one year old. The best results were in children operated on between the ages of one and two years [32]. In general, patients operated before 6 months of age had higher failure rate. This is because the smaller feet may be more deformed, and the anatomy is difficult to judge at the time of surgery. Some foot deformities may improve as the child grows, especially when the child starts to weight bear. It is easier to judge the amount of correction necessary when the child is able to stand on his or her feet. The other problem with early surgery is that it may result in overlengthening the Achilles tendon and in a weakness of plantar flexion [33]. Our lastet follow up were the same those authors's results.

From our results in this study, the patients were operated when they were younger 12 months old with results in group1 (selective soft tissue release only) the same other author's results (see Tables 8 and 9). But Excellent or good results in the group 2 (selective soft tissue release combined decancellous cuboid) were higher group 1 and without poor results when patient's age at time operation older 12 months (see Table 10)

Correction of the varus deformity by displacing the navicular laterally in relation to the head of the talus is the key to successful treatment of clubfoot [34]. The first step in the correction of a club foot should be replacement of the navicular bone on the talus; when this has been done the cuboid bone will have been pushed laterally and it will have taken with it the anterior end of the calcaneum which will have swung clear of the anterior end of the talus [35].

If navicular subluxation is present a medial release is also required, with division of the ligaments between the talus, navicular and medial cuneiform bones, reduction of the navicular and possibly lengthening of the tendon of the posterior tibial muscle [36]. All patient were sectioned those ligaments and lengthening of the tendon of the posterior tibial muscle in this study.

\subsection{Talonavicular Subluxation}

Talonavicular subluxation is more important but often remains undetected in young children because ossification of the navicular does not begin earlier than 2 years of age. Because results with this standardized limited release were satisfactory in most patients in the current study, a radical peritalar release [20,21] in patients younger than 1 year is necessary only if the talonavicular subluxation persists after conservative treatment. In our patients, the talonavicular joint capsulotomy at superior, medial, and inferior surfaces to allow free lateral movement of the navicular on the talus, and after derotative pronation and adduction of foot effective lateral movement of navicular and improvement the talonavicular subluxation and Macnicol's opinion that the talonavicular joint can be reduced adequately by abducting the 
Table 8. Age at time operation and last results.

\begin{tabular}{|c|c|c|c|c|c|c|c|c|c|}
\hline \multirow{2}{*}{$\begin{array}{l}\text { Age at time operation } \\
\qquad \& \text { Foot number }\end{array}$} & \multicolumn{2}{|c|}{ Excellent } & \multicolumn{2}{|c|}{ Good } & \multicolumn{2}{|c|}{ Fair } & \multicolumn{2}{|c|}{ Poor } & \multirow[t]{2}{*}{ Failure } \\
\hline & Group 1 & Group 2 & Group 1 & Group 2 & Group 1 & Group 2 & Group 1 & Group 2 & \\
\hline \multicolumn{10}{|l|}{4 - 6 months old: } \\
\hline Foot number G.1: 40 & 8 & 7 & 16 & 17 & 14 & 2 & 2 & 1 & 0 \\
\hline Foot number G.2: 27 & $(20 \%)$ & $(25.9 \%)$ & $(40 \%)$ & $(63.0 \%)$ & $(35 \%)$ & $(7.4 \%)$ & $(5.0 \%)$ & $(3.7 \%)$ & \\
\hline \multicolumn{10}{|l|}{6 - 12 months old: } \\
\hline Foot number G.1: 63 & 10 & 8 & 35 & 25 & 16 & 3 & 2 & 1 & \\
\hline Foot number G.2: 37 & $(15.9 \%)$ & $(21.6 \%)$ & $(55.5 \%)$ & $(67.6 \%)$ & $(25.4 \%)$ & $(8.1 \%)$ & $(3.2 \%)$ & $(2.7 \%)$ & 0 \\
\hline \multicolumn{10}{|l|}{12 - 18 months old: } \\
\hline Foot number G.1: 107 & 41 & 49 & 52 & 26 & 10 & 5 & 4 & & \\
\hline Foot number G.2: 80 & $(38.3 \%)$ & $(61.3 \%)$ & $(48.6 \%)$ & $(32.5 \%)$ & $(9.4 \%)$ & $(6.2 \%)$ & $(3.7 \%)$ & 0 & 0 \\
\hline \multicolumn{10}{|l|}{18 - 24 months old: } \\
\hline Foot number G.1: 58 & 19 & 27 & 29 & 8 & 9 & 1 & 1 & 0 & 0 \\
\hline Foot number G.2: 36 & $(32.8 \%)$ & $(75.0 \%)$ & $(50.0 \%)$ & $(22.2 \%)$ & $(15.5 \%)$ & $(2.8 \%)$ & $(1.7 \%)$ & & 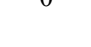 \\
\hline \multirow{2}{*}{ Total } & 78 & 91 & 132 & 76 & 49 & 11 & 9 & 2 & \\
\hline & $(29.1 \%)$ & $(50.6 \%)$ & $(49.3 \%)$ & $(42.2 \%)$ & $(18.3 \%)$ & $(6.1 \%)$ & $(3.3 \%)$ & $(1.1 \%)$ & \\
\hline
\end{tabular}

Table 9. Age at time operation (younger and older 24 months) and last results.

\begin{tabular}{|c|c|c|c|c|c|c|c|c|c|}
\hline \multirow{2}{*}{$\begin{array}{l}\text { Age at time operation } \\
\& \text { Foot number }\end{array}$} & \multicolumn{2}{|c|}{ Excellent } & \multicolumn{2}{|c|}{ Good } & \multicolumn{2}{|c|}{ Fair } & \multicolumn{2}{|c|}{ Poor } & \multirow[t]{2}{*}{ Failure } \\
\hline & Group 1 & Group 2 & Group 1 & Group 2 & Group 1 & Group 2 & Group 1 & Group 2 & \\
\hline \multicolumn{10}{|l|}{$<12$ months old: } \\
\hline Foot number G.1: 103 & 18 & 15 & 51 & 42 & 30 & 5 & 4 & 2 & 0 \\
\hline Foot number G.2: 64 & $(17.5 \%)$ & $(23.5 \%)$ & $(49.5 \%)$ & $(65.6 \%)$ & $(29.1 \%)$ & $(7.8 \%)$ & $(3.9 \%)$ & $(3.1 \%)$ & \\
\hline \multicolumn{10}{|l|}{ >12 months old: } \\
\hline Foot number G.1: 165 & 60 & 76 & 81 & 34 & 19 & 6 & 5 & 0 & 0 \\
\hline Foot number G.2: 116 & $(36.4 \%)$ & $(65.5 \%)$ & $(49.1 \%)$ & $(29.3 \%)$ & $(11.5 \%)$ & $(5.2 \%)$ & $(3.0 \%)$ & & \\
\hline
\end{tabular}

forefoot [37]. Thus, Simons' [38] findings that talonavicular subluxation was present in each case in which the talo-first metatarsal angle on the AP view was greater than $15^{\circ}$ and combined with a talocalcaneal angle of less than $15^{\circ}$ are helpful. We identified talonavicular subluxation according to Simson's opinion with preoperatively 92 of 268 feet (34.3\%) in the group 1, and 69 of 180 feet $(38.3 \%)$ in the group 2 were presented talonavicular subluxation. Final follow up, this deformyties remaining 43 of 268 feet (16.1\%) in the group 1, and 15 of 180 feet $(8.3 \%)$ in the group 2 were presented talonavicular subluxation.

\subsection{Selective Soft Tissue Release}

There are many areas which are open to debate. Should the interosseous subtalar ligaments be transected? Is a calcaneocuboid release required [5]? Do the tendons of flexor hallucis longus and flexor digitorum merit elongation or not? Should the naviculomedial cuneiform joint be opened? How extensively should the cavus be released?

Some muscle could be responsible for adductor foot such as tibialis posterior muscle [39], abductor hallucis [40]. There are several theories in the literature as to the cause of forefoot adduction in clubfoot. Steytler and Van 
Table 10. Compare result and age at time operation of patient younger and older 12 months with other authors.

\begin{tabular}{|c|c|c|c|c|c|c|c|c|c|c|c|c|c|}
\hline \multirow{2}{*}{ Authors } & \multicolumn{3}{|c|}{ Excellent } & \multicolumn{3}{|c|}{ Good } & \multicolumn{3}{|c|}{ Fair } & \multicolumn{3}{|c|}{ Poor } & \multirow[t]{2}{*}{ Failure } \\
\hline & $\begin{array}{c}\leq 6 \\
\text { months }\end{array}$ & $\begin{array}{c}7-12 \\
\text { months }\end{array}$ & $>1$ year & $\begin{array}{c}\leq 6 \\
\text { months }\end{array}$ & $\begin{array}{c}7-12 \\
\text { months }\end{array}$ & $>1$ year & $\leq 6$ months & $\begin{array}{c}7-12 \\
\text { months }\end{array}$ & $>1$ year & $\begin{array}{c}\quad \leq 6 \\
\text { months }\end{array}$ & $\begin{array}{c}7-12 \\
\text { months }\end{array}$ & $>1$ year & \\
\hline Kuo KN & 6 & 44 & 17 & 3 & 21 & 10 & 5 & 3 & 4 & 9 & 13 & & \\
\hline [34] & $27.3 \%$ & $54.3 \%$ & $54.8 \%$ & $13.6 \%$ & $25.9 \%$ & $32.3 \%$ & $22.7 \%$ & $3.7 \%$ & $12.9 \%$ & $36.9 \%$ & 16.1 & 0 & 0 \\
\hline \multirow{2}{*}{$\begin{array}{c}\text { Heiko et al. } \\
\text { [23] }\end{array}$} & & 27 & & & 79 & & & 23 & & & 4 & & \multirow{2}{*}{0} \\
\hline & & $20.3 \%$ & & & $59.4 \%$ & & & $17.3 \%$ & & & $3.0 \%$ & & \\
\hline Hung NN & 8 & 10 & 60 & 16 & 35 & 81 & 14 & 16 & 19 & 2 & 2 & 5 & \multirow{2}{*}{0} \\
\hline Group 1 & $20.0 \%$ & $15.9 \%$ & $36.4 \%$ & $40.0 \%$ & $55.5 \%$ & $49.1 \%$ & $35.0 \%$ & $25.4 \%$ & $11.5 \%$ & $5.0 \%$ & $3.2 \%$ & $3.0 \%$ & \\
\hline Hung NN & 7 & 8 & 76 & 17 & 25 & 34 & 2 & 3 & 6 & 1 & 1 & \multirow{2}{*}{0} & \multirow{2}{*}{0} \\
\hline Group 2 & $25.9 \%$ & $21.6 \%$ & $65.6 \%$ & $63 \%$ & $67.6 \%$ & $29.3 \%$ & $7.4 \%$ & $8.1 \%$ & $5.2 \%$ & $3.7 \%$ & $2.7 \%$ & & \\
\hline
\end{tabular}

der Walt [41] suggested that internal tibial torsion was responsible for this deformity; this is very unlikely because the very existence of internal tibial torsion in clubfoot has been refuted by other authors $[42,43]$.

Haft et al. [44] reported a $41 \%$ rate of early recurrence following the use of the Ponseti method and Park et al. [10] found recurrent or residual deformity in 19 of 48 feet $(40 \%)$.

Flexion of the toes started to improve spontaneously within the first three months after surgery. Six months after surgery there was no noticeable difference between the two sides. On further follow-up, at a mean of four years after surgery, the toes remained well aligned on both sides. They would therefore suggest that the tendons of FHL and FDL may be simply decompressed and not formally lengthened during surgery for resistant club foot. We did not lengthen FHL and FDL for all feet in this study and at final follow up, the toes remained well aligned on both sides [45].

The severity of deformity dictates the structures that need to be released: 1) Equinus: Achilles tendon and gastrocsoleus, Posterior capsule of the ankle joint, and Posterior talofibular ligament; 2) Hindfoot varus: Tibialis posterior, Medial capsule of the subtalar joint, Superficial deltoid ligament, and Calcaneofibular ligament; 3) Forefoot adduction: Tibialis posterior, Abductor hallucis, Medial capsules of the talonavicular joint and the calcaneocuboid joints, and Spring ligament; and 4) Forefoot equinus (cavus): Plantar fascia. and Short plantar muscles [46].

Tendo Achillis lengthening is indicated for equinus deformities, and can be done either by open tendon lengthening or by percutaneous tenotomy. Percutaneous Achilles tenotomy can be performed safely under the age of 18 months [47]. All our patients were younger 24 months have been performed tendo Achillis lengthening by percutaneous tenotomy without difficultly and safely (cf. Figures 7 and 8). Dietz [47] while performing tendoAchillis lengthening under the posteromedial skin incision over the calf, found that the tibialis posterior tendon had hypertrophied. We preformed Percutaneous Achilles tenotomy and lengthening posterior tibial tendon for all patients.

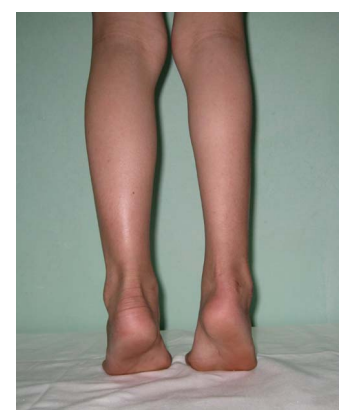

Figure 7. Postoperative 15 years. Patient could be standed his toes.

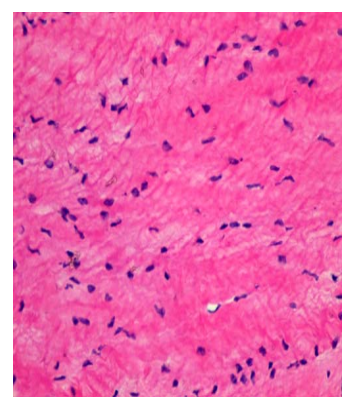

Figure 8. Health of achilles tendon in anapathology postoperative 15 years. 
We agree Jose's opinion [48] that when surgical correction of talipes equinovarus is needed, the posterior capsule and the posterior talofibular ligament may not need to be released. They suggested that the posterior talofibular ligament should be transected only if it shows tension in dorsiflexion. The section of the tibio-fibular ligaments and trimming of the talus were considered [35]. We did not release posterior talofibular ligament all feet in this study.

The deltoid ligament consists of several parts. One part of the deltoid ligament, referred to as the deep deltoid ligament (anterior tibiotalar part of the deltoid ligament), is attached to the talus and, in the opinion of many surgeons, should not be divided to avoid the complication of lateral subluxation of the talus [37].

\subsection{Surgical Bone for Congenital Club Foot}

The length disproportion between the medial and lateral columns of the midfoot has been cited as "the essential deformity" in clubfoot [49]. In an infant's foot, this discrepancy can usually be overcome with casting or soft tissue releases. After adaptive bony deformity is present in the older child, however, soft tissue releases alone are no longer adequate to achieve correction. Other procedures to shorten the lateral column have also been reported, such as resection of the distal end of the calcaneus and resection-arthrodesis of the calcaneocuboid joint $[49,50]$. Procedures that lengthen the deficient medial column have also been described. Hofmann et al. [51] reported results with Fowler's technique of a medial opening wedge osteotomy in the first cuneiform [52]. They used the procedure to correct residual forefoot adductus and cavus in previously treated clubfeet in children aged 4 to 15 . The adductus was corrected by an average of $72 \%$, as determined by improvement in the talo-first metatarsal angle. A normally aligned hindfoot was a prerequisite in their series. Kling et al. [53] described a similar procedure combined with capsulotomies of the second through fourth tarsometatarsal joints. Lowe and Hannon [54] noted abnormal obliquity in the medial cuneiform - first metatarsal joint in $73 \%$ of treated clubfeet with residual forefoot adductus on the AP radiograph. Using a combination of osteotomies, one shortening the lateral column and the other lengthening the medial column and correcting the angulation of the first metatarsal cuneiform joint, provides the advantage of attaining more correction than either procedure alone. McHale and Lenhart [55] first reported good correction of the forefoot using this procedure in patients with residual forefoot adductus caused by talipes equinovarus. Schaefer and Hefti [56] used this combination of osteotomies in the treatment of clubfeet and found it to be useful in the treatment of idiopathic talipes equinovarus. However, they noted concerning recurrences in patients followedup for more than 6 years. Lourenco et al. [57] reported the radiographic improvement in all patients without complications in 39 clubfeet.

Evans procedure [35] cuboid wedge resection and decancelation can adequately address some midfoot deformities; however, they do not correct adduction occurring distal to the talonavicular and calcaneocuboid joints or supination. They have failed because they attacked either the medial column of the foot, such as the head of the talus or the talo-navicular joint, or the wrong part of the lateral column. It is obviously wrong to shorten or weaken the medial bony column of the foot; The next step, excision of the calcaneo-cuboid joint, is the critical stage of the operation. So far, nothing has been done except to make correction of deformity possible by releasing contracted tissues. Johanning [58] described wedge resection and enucleation of the cuboid followed by manipulation and casting as treatment of resistant clubfoot. Evans and Johanning procedures performed clubfeet in older children and adolescents.

The removed wedge from shortening of the cuboid bone can be inserted into the osteotomized and distracted osteotomy gap of the medial cuneiform bone for lengthening purposes. However, in some cases, the cuboid bone is soft or the wedge is too small for adequate support of lengthening the medial cuneiform $[33,36]$. Children younger 24 months, wedge osteotomy of cuboid distracted osteotomy gap of the medial cuneiform bone was very difficultly. Under-correction and over-correction result from lack of care when excising the calcaneo-cuboid joint. The wedge of bone which is excised must be of the right thickness; removal of insufficient bone will not fully correct the deformity and removal of too much bone will over-correct it. The possible wider significance of this and the remedy for over-correction [28]. We performed decancellous and collapse of cuboid instead of wedge osteotomy of cuboid.

Our surgical procedure involving medial selective soft tissue release and decancelation of cuboid bone without capsulotomy of the cancaneocuboid joint and cuboid wedge resection followed by derotative pronation and abductive foot with international fixation by Kirschner wire through cuboid and calcaneus. So the preventing clash between of canlcaneo-cuboid-five metatarsal bones. The final follow up, radiographic evidence without abnormal those bone or osteoarthritic or degenerative changes and cuboid was not avascular necrotic at the late follow-up visit.

Our surgical procedure with Purpose: 1) the capsule of the talo-navicular joint is divided on its superior, medial, and inferior surfaces to allow free lateral movement of the navicular on the talus, improve talonavicular sub- 
luxation; 2) A shortening of lateral column and an elongated lateral column with talo-navicular joint capsulotomy, cuboid collapse by decancelous cuboid and derotative pronation and abductive foot; and 3) Long time follow-up, radiographic evidence of delayed development of cuboid bone (cf. Figure 9). Our results confirmed good correction of forefoot adduction and cavus deformity.

We have seen some error of technique: 1) injury of cuboid cartilagenious capsule in one foot (cf. Figure 10);

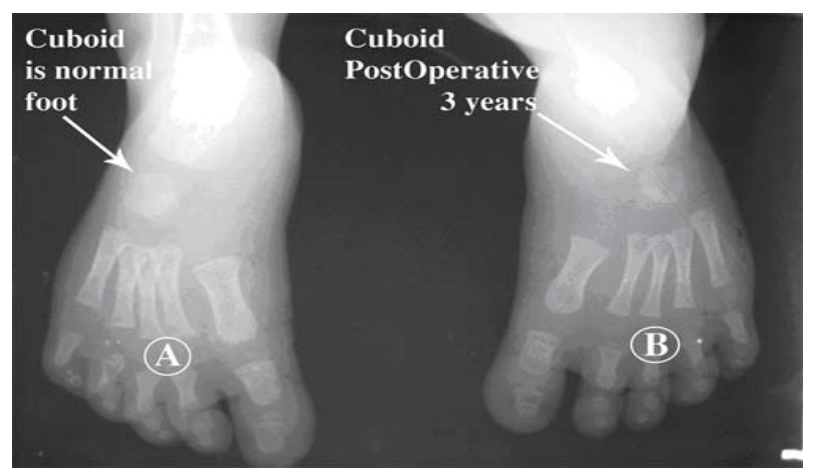

Figure 9. (A) normal foot; (B) postoperative 3 years cuboid was smaller than normal foot.
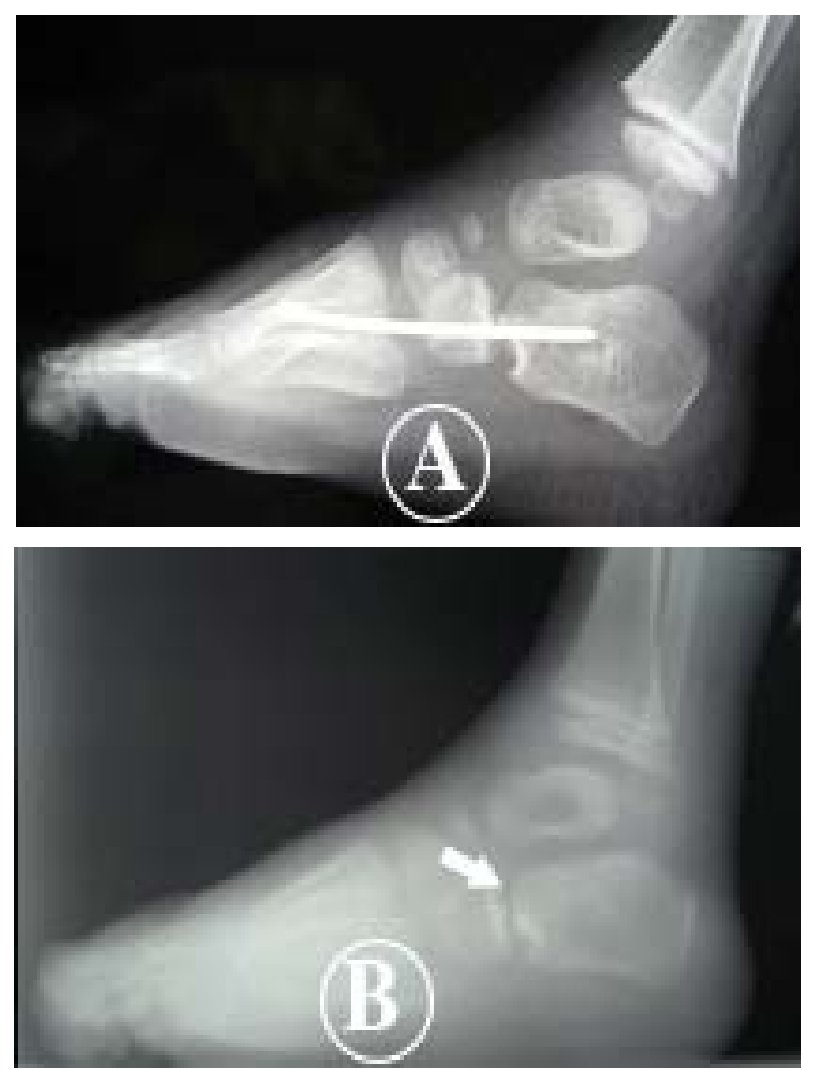

Figure 10. (A) Postoperatively, injury of cuboid cartilagenious capsule on 3 months; (B) postoperative 5 years, degenerative cubocalcaneal joints.
So, when remove cancellous cuboid gently and always check cancellous was removed, if see cartilagenious capsule should stop; 2) Slide down of Kirchner wire was fixed cuboid and calcaneus in one foot (cf. Figure 11). Postoperatively 4 weeks, this foot with slided down plaster cast in two time. So, should follow close behind fat patient and could postoperative plaster cast above knee and knee flexion $30^{\circ}-45^{\circ}$ in $4-6$ weeks.

The recurrence rate is known to be highest at one to three years of age, when the foot is growing rapidly [59], and our all patients were older 5 years at lates follow up.

Moreover, the results of treatment in different series are very difficult to compare because of different degrees of severity at birth, differences in treatment, and use of different rating systems to assess the results [5].

Our final follow up attained excellent or good results in selective soft tissue release and decancelous cuboid involved in $92.8 \%$ and poor result in $1.1 \%$ only in group 2 (Table 11). The limitation of this study is a relatively short followup for clubfoot in group 2 and long-term follow-up to skeletal maturity will be necessary.

\section{Conclusions}

1) Because conventional radiography cannot give any reliable information at this young age, one has to be content with the clinical examination in the decision regarding
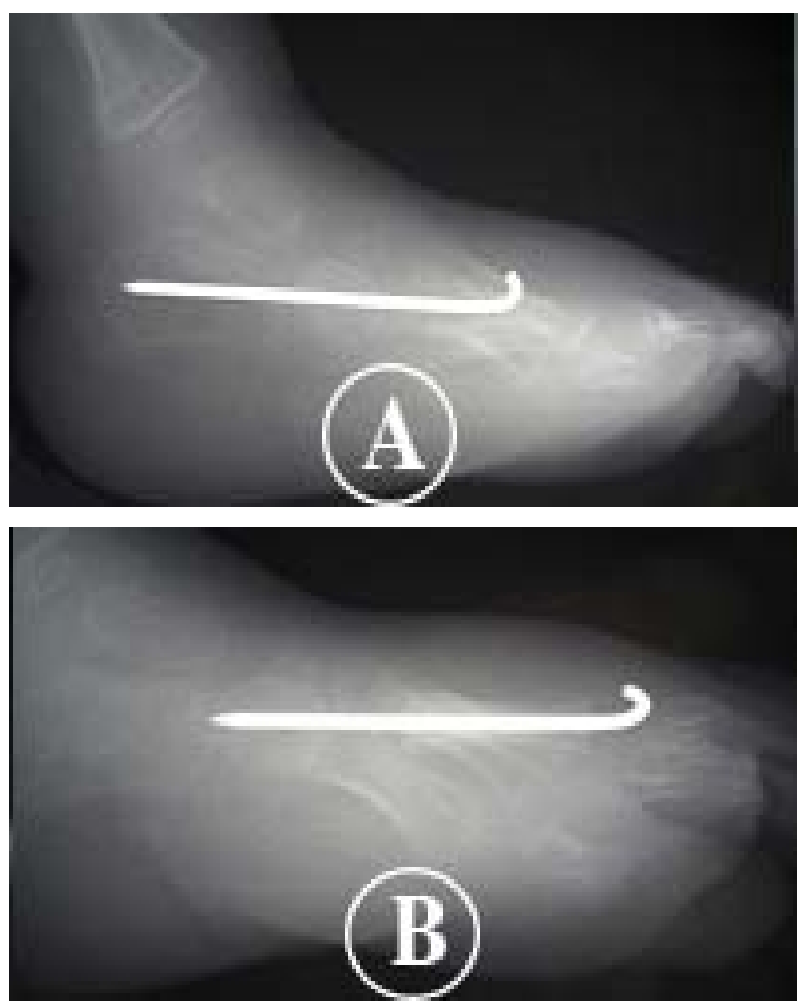

Figure 11. (a) Postoperative 3 weeks; (b) Slide down of Kirchner wire postoperative 4 weeks. 
Table 11. Our follow up results in comparison with other authors.

\begin{tabular}{|c|c|c|c|c|c|c|c|}
\hline \multirow{2}{*}{ Authors } & \multirow{2}{*}{$\begin{array}{l}\text { No. } \\
\text { foot }\end{array}$} & \multirow{2}{*}{ Surgical procedure } & \multirow{2}{*}{ Rating system } & \multicolumn{3}{|c|}{ Resutls } & \multirow{2}{*}{ Follow up } \\
\hline & & & & Excellent or Good & Fair & Poor & \\
\hline McKay [20] & 55 & Peritalar release & McKay & $70 \%$ & & & 3.2 years \\
\hline Heiko et al. [60] & 133 & Posteroplantar & McKay & $79.7 \%$ & $17.3 \%$ & $3 \%$ & $3-12$ years \\
\hline Hung NN & 268 & Selective soft tissue release & McKay & $78.4 \%$ & $18.3 \%$ & $3.3 \%$ & 11 - 21years \\
\hline Hung NN & 180 & $\begin{array}{l}\text { Selective soft tissue release is } \\
\text { combined decancellous cuboid }\end{array}$ & McKay & $92.8 \%$ & $6.1 \%$ & $1.1 \%$ & $6-11$ years \\
\hline Kausch et al. [61] & 123 & Posteromedial release & Magone & $64 \%$ & & & 6 years \\
\hline R. Krauspe and K. Parsch [62] & 60 & Peritalar release & McKay & $76 \%$ & & & $2-5$ years \\
\hline V. J. Turco [32] & 144 & Posteromedial release & Turco & $84 \%$ & $10.7 \%$ & $5.3 \%$ & 2 - 15years \\
\hline Bensahel et al. [11] & 101 & Posteromedial release & Bensahel & $88 \%$ & & & $6-10$ years \\
\hline Hudson and Catterall [19] & 53 & Posterolateral release & $\begin{array}{c}\text { Green and } \\
\text { Lloyd-Roberts }\end{array}$ & $92.5 \%$ & & $7.5 \%$ & $\begin{array}{c}18 \text { months - } 14 \\
\text { years }\end{array}$ \\
\hline
\end{tabular}

the type of surgery, should consider the clinical examination and document of radiographicss invonlved for type of the surgical intervention needed in idiopathic clubfoot, prognosis, and follow up.

2) Postoperative residual deformity was most adductor forefoot and initially operate clubfeet should soft tissue release and decancelous cuboid involved for children youger 24 months; Postoperative excellent or good results in $92.8 \%$, fair or poor results in $7.2 \%$ only in group 2.

\section{REFERENCES}

[1] R. Wynne-Davies, "Genetic and Environmental Factors in the Etiology of Talipes Equinovarus," Clinical Orthopaedics and Related Research, Vol. 84, 1972, pp. 9-13. doi:10.1097/00003086-197205000-00003

[2] R. K. Beals, "Club Foot in the Maori: A Genetic Study of 50 Kindreds," New Zealand Medical Journal, Vol. 88, 1978, pp. 144-146.

[3] F. H. Geoffrey, G. W. Cameron and A. C. Haemish, "Early Clubfoot Recurrence after Use of the Ponseti Method in a New Zealand Population," The Journal of Bone \& Joint Surgery, Vol. 89, No. 3, 2007, pp. 487-493. doi:10.2106/JBJS.F.00169

[4] A. H. Matthew, E. D. Jan, H. Jen-Chen, G. W. Cameron, J. W. Stewart and A. C. Haemish, "Ponseti Method Compared with Surgical Treatment of Clubfoot. A Prospective Comparison," Journal of Bone \& Joint Surgery, Vol. 92, No. 2, 2010, pp. 270-278. doi:10.2106/JBJS.H.01560

[5] E. Ippolito, P. Fatsetti, R. Caterini and C. Tudisco, "LongTerm Comparative Results in Patients with Congenital Clubfoot Treated with Two Different Protocols," The Journal of Bone \& Joint Surgery, Vol. 85A, No. 7, 2003, pp. 1286-1294.

[6] D. M. Cooper and F. R. Dietz, "Treatment of Idiopathic
Clubfoot. A Thirty-Year Follow-Up Note," The Journal of Bone \& Joint Surgery, Vol. 77A, 1995, pp. 1477-1489.

[7] S. J. Laaveg and I. V. Ponseti, "Long-Term Results of Treatment of Congenital Club Foot," The Journal of Bone \& Joint Surgery, Vol. 62A, 1980, pp. 23-31.

[8] M. B. Dobbs, J. R. Rudzki, D. B. Purcell, T. Walton, K. R. Porter and C. A. Gurnett, "Factors Predictive of Outcome after Use of the Ponseti Method for the Treatment of Idiopathic Clubfeet," The Journal of Bone \& Joint Surgery, Vol. 86A, 2004, pp. 22-27.

[9] J. A. Morcuende, L. A. Dolan, F. R. Dietz and I. V. Ponseti, "Radical Reduction in the Rate of Extensive Corrective Surgery for Clubfoot Using the Ponseti Method," Pediatrics, Vol. 113, No. 2, 2004, pp. 376-380. doi:10.1542/peds.113.2.376

[10] S. S. Park, S. W. Kim, B. S. Jung, H. S. Lee and J. S. Kim, "Selective Soft-Tissue Release for Recurrent or Residual Deformity after Conservative Treatment of Idiopathic Clubfoot," The Journal of Bone \& Joint Surgery, Vol. 91B, No. 11, 2009, pp. 1526-1530. doi:10.1302/0301-620X.91B11.22327

[11] H. Bensahel, Z. Csukonyi, Y. Desgrippes and J. P. Chaumien, "Surgery in Residual Clubfoot: One-Stage Medioposterior Release a la Carte," Journal of Pediatric Orthopaedics, Vol. 7, No. 2, 1987, pp. 145-148. doi:10.1097/01241398-198703000-00005

[12] A. H. Crawford and A. K. Gupta, "Clubfoot Controversies: Complications and Causes for Failure," Instructional Course Lectures, Vol. 45, No. 3, 1996, pp. 39-46.

[13] J. H. Kite, "Errors and Complications in Treating Foot Conditions in Children," Clinical Orthopaedics and Related Research, Vol. 53, 1967, pp. 31-38. doi:10.1097/00003086-196707000-00005

[14] I. V. Ponseti, "Treatment of Congenital Clubfoot," The Journal of Bone \& Joint Surgery, Vol. 74A, 1992, pp. 448-454.

[15] C. G. Attenborough, "Early Posterior Soft-Tissue Release 
in Severe Congenital Talipes Equinovarus," Clinical Orthopaedics and Related Research, Vol. 84, 1972, pp. 7178. doi:10.1097/00003086-197205000-00014

[16] A. D. L. Green and G. C. Lloyd-Roberts, "The Results of Early Posterior Release in Resistant Club Feet: A LongTerm Review," The Journal of Bone \& Joint Surgery, Vol. 67B, 1985, pp. 588-593.

[17] G. Imhäuser, "Die Frühbehandlung des Angeborenen, Muskulären Klumpfusses," Monatsschr Kinderheilkd, Vol. 117, 1969, pp. 645-655.

[18] I. Reimann and H. Becker-Andersen, "Early Surgical Treatment of Congenital Clubfoot," Clinical Orthopaedics and Related Research, Vol. 102, 1974, pp. 200-206. doi:10.1097/00003086-197407000-00024

[19] I. Hudson and A. Catterall, "Posterolateral Release for Resistant Clubfoot," The Journal of Bone \& Joint Surgery, Vol. 76B, 1994, pp. 281-284.

[20] D. W. McKay, "New Concept of and Approach to Clubfoot Treatment: Section III. Evaluation and Results," Journal of Pediatric Orthopaedics, Vol. 3, 1983, pp. 141148. doi:10.1097/00003086-197407000-00024

[21] G. W. Simons, "Complete Subtalar Release in Clubfeet. Part I. A Preliminary Report," The Journal of Bone \& Joint Surgery, Vol. 67A, 1985, pp. 1044-1055.

[22] I. V. Ponseti, "Congenital Clubfoot. Fundamentals for Treatment," Oxford University Press, Oxford, 1996, p. 55.

[23] A. Diméglio, H. Bensahel, P. Souchet, P. Mazeau and F. Bonnet, "Classification of Clubfoot," Journal of Pediatric Orthopaedics B, Vol. 4, No. 2, 1995, pp. 129-136. doi:10.1097/01202412-199504020-00002

[24] I. V. Ponseti, G. Y. El-Khoury, E. Ippolito and S. L. Weinstein, "A Radiographic Study of Skeletal Deformities in Treated Clubfeet," Clinical Orthopaedics and Related Research, Vol. 160, 1981, pp. 30-42.

[25] R. Vanderwilde, L. T. Staheli, D. E. Chew and V. Malagon, "Measurements on Radio-Graphs of the Foot in Normal Infants and Children," Journal of Bone \& Joint Surgery of American, Vol. 70, 1988, pp. 407-415.

[26] V. I. Ponseti and E. N. Smoley, "Congenital Club Foot: The Results of Treatment," Journal of Bone \& Joint Surgery of American, Vol. 45A, 1963, pp. 261-344.

[27] A. J. Harrold and C. J. Walker, "Treatment and Prognosis in Congenital Club Foot," Journal of Bone \& Joint Surgery of British, Vol. 65B, 1983, pp. 8-11.

[28] A Catterall, "A Method of Assessment of the Clubfoot Deformity," Clinical Orthopaedics and Related Research, Vol. 264, 1991, pp. 48-53.

[29] C. Tuncay, A. E. Bagatur, O. Tahir and A. Taner, "Comparison of the Soft-Tissue Release Methods in Idiopathic Clubfoot," Journal of Pediatric Orthopaedics, Vol. 20, 2000, pp. 648-651. doi:10.1097/01241398-200009000-00019

[30] H. Yamamoto, T. Muneta and S. Morita, "Nonsurgical Treatment of Congenital Clubfoot with Manipulation, Cast, and Modified Denis Browne Splint," Journal of Pediatric Orthopaedics, Vol. 18, 1998, pp. 538-542.

\section{doi:10.1097/01241398-199807000-00027}

[31] J. G. Pous, "A Dimeglio Neonatal Surgery in Clubfoot," Orthopedic Clinics of North America, Vol. 9, 1978, pp. 233-240.

[32] V. J. Turco, "Resistant Congenital Clubfoot One Stage Posteromedial Release with Internal Fixation. A FollowUp Report of a Fifteen-Year Experience," The Journal of Bone \& Joint Surgery, Vol. 61A, 1979, pp. 805-814.

[33] K. N. Kuo and A. S. Peter, "Correcting Residual Deformity Following Clubfoot Releases," Clinical Orthopaedics and Related Research, Vol. 467, 2009, pp. 13261333. doi:10.1007/s11999-008-0664-y

[34] S. M. Mardjetko, J. P. Lubicky, K. N. Kuo and C. Smrcina, "Pseudoaneurysm after Foot Surgery," Journal of Pediatric Orthopaedics, Vol. 11, 1991, pp. 657-662.

[35] D. Evans, "Relapsed Club Foot," Journal of Bone \& Joint Surgery of British, Vol. 43, 1961, pp. 722-733.

[36] C. Hasler, "Congenital Clubfoot," In: F. Hefti, Ed., Pediatric Orthopedics in Practice, Springer-Verlag, Berlin 2007, pp. 374-388.

[37] J. L. Goldner, "Congenital Talipes Equinovarus: Fifteen Years of Surgical Treatment," Current Practice in Orthopaedic Surgery, Vol. 4, 1969, p. 61.

[38] G. W. Simons, "Analytical Radiography of Clubfeet," The Journal of Bone \& Joint Surgery, Vol. 59B, 1977, pp. 485-489.

[39] A. Fried, "Recurrent Congenital Clubfoot: The Role of the Tibialis Posterior in Etiology and Treatment," The Journal of Bone \& Joint Surgery, Vol. 41, 1959, pp. 243252.

[40] M. F. Macnicol and L. L. Flocken, "Calcaneocuboid Malalignment in Club Foot," Journal of Pediatric Orthopaedics $B$, Vol. 8, 1999, pp. 257-260.

[41] J. C. S. Steytler and I. D. Van der Walt, "Correction of Resistant Adduction of the Forefoot in Congenital Clubfoot and Congenital Metatarsal Varus by Metatarsal Osteotomy," Journal of Bone \& Joint Surgery of British, Vol. 53, 1966, pp. 558-560.

[42] N. C. Carroll, "Clubfoot," In: R. T. Morrisy, Ed., Lovell and Winter's Pediatric Orthopaedics, 3rd Edition, JB Lippincott, Philadelphia, 1990, pp. 927-956.

[43] M. Swann and G. C. Lloyd-Roberts, "A Catterall. The Anatomy of Uncorrected Clubfeet," Journal of Bone \& Joint Surgery of British, Vol. 51, 1969, pp. 263-269.

[44] G. F. Haft, C. G. Walker and H. A. Crawford, "Early Clubfoot Recurrence after Use of the Ponseti Method in a New Zealand Population," Journal of Bone \& Joint Surgery of American, Vol. 89A, 2007, pp. 487-493. doi:10.2106/JBJS.F.00169

[45] S. S. Park, S. W. Kim, B. S. Jung, H. S. Lee and J. S. Kim, "Selective Soft-Tissue Release for Recurrent or Residual Deformity after Conservative Treatment of Idiopathic Clubfoot," Journal of Bone \& Joint Surgery of British, Vol. 91B, 2009, pp. 1526-1530. doi:10.1302/0301-620X.91B11.22327

[46] N. Selvadurai, "Equinovarus in Paediatric Orthopaedics: 
A System of Decision On-King," Journal of Nayagam, Loder and Torode, 2009, pp. 16-29.

[47] F. R. Dietz, "Treatment of a Recurrent Clubfoot Deformity after Initial Correction with the Ponseti Technique," AAOS Instructional Course Lectures, Vol. 55, 2006, pp. 625-629.

[48] A. Jose'Herrera-Soto, "Pediatric Foot and Ankle Disorders," Current Opinion in Orthopaedics, Vol. 15, 2004, pp. 417-422. doi:10.1097/01.bco.0000146122.77502.77

[49] E. E. Berg, "A Reappraisal of Metatarsus Adductus and Skewfoot," Journal of Bone \& Joint Surgery of American, Vol. 68, 1986, pp. 1185-1196.

[50] D. A. Cook, A. L. Breed, T. Cook, A. DeSmet and C. M. Muehle, "Observer Variability in the radiographic Measurement and Classification of Metatarsus Adductus," Journal of Pediatric Orthopaedics, Vol. 12, 1992, pp. 8689.

[51] A. Hofmann, R. Constine and G. McBride, "Osteotomy of the First Cuneiform as a Treatment of Resistant Adduction of the Fore Part of the Foot in Congenital Clubfoot or Congenital Metatarsus Varus," Journal of Bone \& Joint Surgery of American, Vol. 40, 1958, pp. 299-310.

[52] S. B. Fowler, A. L. Brooks and T. F. Parrish, "The CavoVarus Foot," Journal of Bone \& Joint Surgery of American, Vol. 41, 1959, p. 757.

[53] T. F. Kling, T. L. Schmidt and M. J. Conklin, "Opening Wedge Osteotomy of the First Cuneiform for Metatarsus Adductus," Orthopedic Transactions, Vol. 15, 1991, p. 106.

[54] L. W. Lowe and M. A. Hannon, "Residual Adduction of the Forefoot in Treated Congenital Clubfoot," Journal of Bone \& Joint Surgery of British, Vol. 55, 1973, pp. 809813.

[55] K. A. McHale and M. K. Lenhart, "Treatment of Residual Clubfoot Deformity - The Bean-Shaped Foot—By Open- ing Wedge Medial Cuneiform Osteotomy and Closing Wedge Cuboid Osteotomy, Clinical Review and Cadaver Correlations," Journal of Pediatric Orthopaedics, Vol. 11, 1991, pp. 374-381.

[56] D. Schaefer and F. Hefti, "Combined Cuboid/Cuneiform Osteotomy for Correction of Residual Adductus Deformity in Idiopathic and Secondary Club Feet," Journal of Bone \& Joint Surgery of British, Vol. 82, 2000, pp. 881884. doi:10.1302/0301-620X.82B6.10845

[57] A. F. Lourenco, L. S. Dias, D. M. Zoellick and H. Sodre, "Treatment of Residual Adduction Deformity in Clubfoot: The Double Osteotomy," Journal of Pediatric Orthopaedics, Vol. 21, 2001, pp. 713-718. doi:10.1097/01241398-200111000-00003

[58] K. Johanning, "Excochleatio Ossis Cuboidei in the Treatment of Posequino-Varus," Acta Orthopaedica Scandinavica, Vol. 27, 1958, pp. 310-319.

[59] A. Berman and J. J. Gartland, "Metatarsal Osteotomy for the Correction of Adduction of the Fore Part of the Foot in Children," Journal of Bone \& Joint Surgery of American, Vol. 53, 1971, pp. 498-506.

[60] R. L. Heiko, L. Susanne, M. Ljubinko and H. Werner, "Posteroplantar Release for Congenital Clubfoot in Children Younger than 1 Year," Clinical Orthopaedics and Related Research, Vol. 387, 2001, pp. 183-190. doi:10.1097/00003086-200106000-00025

[61] T. Kausch, J. Rütt, M. H. Hackenbroch and B. Fünfgeld, "Behandlungsergebnisse des Neugeborenenklumpfusses nach Imhäuser,"Zeitschrift Fur Orthopadie, Vol. 133, 1995, pp. 524-529. doi:10.1055/s-2008-1039933

[62] R. Krauspe and K. Parsch, "Peritalare Arthrolyse zur Klumpfusskorrektur über den Cincinnati-Zugang," Operat Orthop Traumatol, Vol. 7, 1995, pp. 125-140. doi:10.1007/BF02512690 